\title{
Astronaut Exposures to lonizing Radiation in a Lightly-Shielded Spacesuit
}

\author{
J. W. Wilson, L. C. Simonsen, J. L. Shinn, M.-H. Y. Kim \\ NASA Langley Research Center \\ F. A. Cucinotta \\ NASA Johnson Space Center \\ F. F. Badavi \\ Christopher Newport University \\ W. Atwell \\ Boeing North American, Inc.
}

\begin{abstract}
The normal working and living areas of the astronauts are designed to provide an acceptable level of protection against the hazards of ionizing radiation of the space environment. Still there are occasions when they must don a spacesuit designed mainly for environmental control and mobility and leave the confines of their better-protected domain. This is especially true for deep space exploration. The impact of spacesuit construction on the exposure of critical astronaut organs will be examined in the ionizing radiation environments of free space, the lunar surface and the Martian surface. The computerized anatomical male model is used to evaluate astronaut self-shielding factors and to determine space radiation exposures to critical radiosensitive human organs.
\end{abstract}

\section{INTRODUCTION}

Solar particle events have long been recorded as large temporal increases in the signals from ground level ion chambers and neutron monitors which are used to study the time variations in the solar-modulated galactic cosmic rays (intermittent studies starting in 1932 and continuous observations since 1946). The largest such ground level event, with increases of nearly 3,600 percent over background levels, occurred on February 23, 1956 (see figure 1). Only those particles above several hundred $\mathrm{MeV}$ contribute to ground levels and the low to medium energy spectrum of this event is very uncertain (1). The low energy flux listed in table 1 for the February 23, 1956 event was estimated by Foelsche (1) and are most uncertain. The November 1960 events were the first for which low energy measurements were made by nuclear emulsion on sounding rockets and electronic detector data collected in space start only with the November 18, 1968 event. Since 1956, several ground level events have occurred of large magnitude but even the largest of these events (2) occurring on September 29, 1989 was only about 350 percent above background (see figure 2), an order of magnitude smaller than the 1956 event. Also shown in figure 2 is the neutron monitor data of the October 19, 1989 event in comparison. The September 29, 1989 event had good coverage in its measured spectrum and was an iron rich event (3) for which there has been some concern over the expected exposures in a lightly-shielded spacesuit from these atypical radiations. It has been suggested that a proxy for the February 23, 1956 event in the low energy region could be taken as 10X the September 29, 1989 event (D. F. Smart, personal communication) and such an event would dominate any other event listed in table 1 . One could then argue that the 10X September 29, 1989 event would be a reasonable worst case design event which has some basis in over 50 years of solar observation. Note that such an event could be expected to occur in the next 50 years.

In an earlier report (4), we considered the biological response to the August 4, 1972 event which spacebased measurements indicated was one of the largest solar particle events (table 1) with potential for serious consequences. In that paper, we found that the protons of importance to exposure of critical body organs were on the range of 20 to over $110 \mathrm{MeV}$. Although the 1972 event was sufficiently intense to cause concern for potentially lethal effects, the repair and recovery within the blood-forming organ (BFO), at least for a 1-g environment, appears sufficient to prevent death for this event. This ability to recover was due to the long time period of the 1972 exposure (over 10 hours). 
Unanswered in that study was the importance of the stress factors associated with flight in space due to microgravity, confinement, etc. These factors could significantly alter the result of the biological model used. For example, mouse studies (5-7) had shown that confinement and housing factors could decrease the lethal dose for killing half the population in the first 30days $\left(\mathrm{LD}_{50}\right)$ by a factor of two which is sufficient to shift a population from high survival to certain mortality. Although the total fluence from the October 9-12, 1989 event(s) was on the order of that observed August 1972, the October event(s) occurred over a three day period in which repair and recovery reduced the injury to a level of little immediate concern even though the NCRP (8) allowable radiation exposure limits (table 2 ) were greatly exceeded.

The February 23, 1956 event and the September 29, 1989 event were both of short duration (see figures 1 and 2) allowing less time for repair and recovery. The use of the 10X September 29, 1989 event as proxy for the February 23, 1956 would undoubtedly be the worst case based on observed data. We will begin the treatment of this event by calculating the total exposures from this event in free space, on the lunar surface, and on the Martian surface.

\section{EXPECTED EXPOSURES}

In a recent paper (9), we constructed an analytic representation of the September 29, 1989 solar particle event using the Nymmik model (10) for protons above 30 $\mathrm{MeV}$ and an exponential distribution (11) below $30 \mathrm{MeV}$, empirical representations of oxygen and iron ion spectra based on the IMP-8 data (3), and extrapolation of the IMP-8 result to the other multiply charged ions using the work of McGuire et al. (12). The resulting spectra are shown in figure 3. The proxy February 23, 1956 event is obtained from figure 3 with a scale factor of 10X.

Spacesuit configurations have been reviewed by A. J. Ross et al. (13). The helmet visor assembly is shown in figure 4 with the material lay-up in table 3 . The spacesuit fabric lay-up is shown in figure 5 with the corresponding materials list in table 4 . In the present calculation, the layups are replaced by equivalent amounts of aluminum. For this calculation, we have ignored the hard upper torso and the life support assemblies. The human geometry model is the computerized anatomical male model (14). In addition to the question of the spacesuit shielding, we will address the question of retreat into a more protected region of aluminum construction. The regions considered for retreat are a simple pressure vessel of $1 \mathrm{~g} / \mathrm{cm}^{2}$ thickness, a modestly equipped room of $5 \mathrm{~g} / \mathrm{cm}^{2}$, or a storm shelter of $10 \mathrm{~g} / \mathrm{cm}^{2}$. We will use the HZETRN code for shield analysis (15). The HZETRN code includes the transport of all baryonic components including neutrons to Ni-58. It does not yet include the mesons and the associated electromagnetic cascades which will increase the present results by no more than 15-20 percent (16). In all of the calculations we will employ the ICRP-60 quality factor (17) although this quantity is not yet officially accepted for use in the space program (8). In evaluation the effects of the estimated exposures we consider not only the NCRP limits which are to be adhered to in the mission design but the exposures for which observable effects are expected to occur as given in table 5 .

\section{FREE SPACE EXPOSURES}

The solar particles are modified by first passing through the materials of the spacesuit. This mainly removes the lowest energy ions without incident. The more energetic ions will undergo nuclear reactions producing ions of a different character (often more penetrating) and neutrons of a broad energy spectrum which more easily escape the shield and enter body tissues. In the case of deep body organs, the radiation is additionally modified in passing through the overlying body tissues. The transmitted charged particles present in skin and BFO tissues are shown in figure 6 . The neutrons are plentiful but only contribute to radiation injury through the charged particle components as shown in the figure. The quantities shown in the figure are differential dose equivalent units per unit lethargy. Consequently, the area under the curves is related to the total exposure. One can see from the figure that low-energy protons and alpha particles are the most important components of the exposure especially for less protected tissues. The HZE ions are seen to play a less important role in the overall exposure.

The dose equivalent components and the total are given in table 6 . The total exposures from this event in free space would be devastating (compare with table 5). The exposure time is only a few hours and the repair and recovery for the skin results in an erythema threshold that is proportional to $t^{0.29}$ providing insufficient repair (only a factor of two to three) to overcome the expression of early effects. It is of interest to note that the ions of charge greater than 2 result in HZE exposures to the skin in excess of the annual galactic cosmic ray exposures but are expected to contribute little to the immediate response of the skin since proton and helium ions dominate the exposure. The added protective qualities of the helmet are clearly seen by comparing the ocular lens (within the helmet) and skin exposures (behind the fabric). Retreat into the equipment room provides insufficient shielding to prevent serious life-threatening exposures to the astronaut from this event. These concerns are further heightened by the fact that they occur in free space under microgravity condition which is expected to shift the $L_{50}$ of the astronaut too much lower values (4).

\section{LUNAR SURFACE EXPOSURES}

In operations on the lunar surface, the astronaut gains from the shadow produced by the moon itself, reducing the exposures by a factor of two. The exposures are shown in table 7 in comparison with allowable exposure limits (8). Clearly, an astronaut in a spacesuit will be in great danger from such an event (compare exposure with table 5). Even the pressure vessel will not provide much protection for the astronaut. Within a wellequipped room, there is an improved chance of survival but sill large exposures are indicated which are well 
outside the range of acceptable limits (8). Some type of shelter will have to be provided to get within acceptable limits for this event.

\section{MARTIAN SURFACE EXPOSURES}

The radiations first penetrate the Martian atmosphere before reaching the Martian surface which must be accounted in exposure estimates during Martian surface operations. The Martian atmosphere is represented by the Low Density COSPAR model as we have used elsewhere (18) and is the most conservative assumption. The overhead air mass is $16 \mathrm{~g} / \mathrm{cm}^{2}$ of mostly carbon dioxide. In this case, the overhead air mass provides significant protection from this event (see table 8). The local tissue environment of three critical body organs is shown in figure 7 . Important contributors to the exposure in this case are the energetic protons of peak energy of $100 \mathrm{MeV}$ and low energy alpha particles of peak energy of $1 \mathrm{MeV} / \mathrm{amu}$. The proton spectrum consists of the uncollided primary radiations and added contributions from nuclear reactions. The HZE particles contribute very little to the exposure since they are brought to rest by the atomic collision process in the atmosphere. The only qualitative change in the tissue environment in moving to the shelter is that the relative contributions of the alpha particles increases with added shielding (fig. 8). This results from the added attenuation of the medium-energy ions while the main source of the alpha particles are the highest energy protons which are relatively unaffected by the increased shelter shield. Note that the proton peak moves to relatively higher energies due to attenuation of the lower energies mainly by atomic collisions.

Even in a spacesuit, the astronaut is reasonably well protected from this event in that the exposure of the critical tissues is small compared to what is required for observable effects (table 5) although the NCRP allowable limit for the BFO is exceeded. The addition of a shelter reduces the exposure to within prescribed 30 day limits as seen in table 8 .

\section{CONCLUSION}

The assumption that the February 23, 1956 solar particle event can be represented by the proxy of 10X the September 29, 1989 event leads to a difficult shield design problem. It is clear that designs based on the August 4, 1972 event series will be inadequate to protect the astronaut from this proxy event. Not only are the allowable limits greatly exceeded but also there is a real possibility of mortality in deep space exploration unless a very massive shelter shield is provided. Even then it is likely that the NCRP limits may be exceeded but without serious immediate medical consequence.

\section{CONTACT}

John W. Wilson, MS 188B, NASA Langley Research Center, Hampton, VA 23681-0001, john.w.wilson@larc.nasa.gov

\section{REFERENCES}

1. T. Foelsche, Current Estimates of Radiation Doses in Space. NASA TN D-1267, 1962.

2. J. E. Humble, M. L. Duldig, D. F. Smart, M. A. Shea, Detection of $0.5-15 \mathrm{GeV}$ protons on 29 September 1989 at Australian stations. Geophys. Res. Lett. 18: 717-740; 1991.

3. A. J. Tylka, W. F. Dietrich, P. R. Boberg, High-energy heavy solar particles from IMP-8. Proc. $25^{\text {th }}$ International Cosmic Ray Conference, 1: 101; 1997.

4. J. W. Wilson, J. L. Shinn, L. C. Simonsen, F. A. Cucinotta, R. R. Dubey, W. R. Jordan, T. D. Jordan, C. K. Chang, M. Y. Kim, Exposures to Solar Particle Events in Deep Space Missions. NASA TP 3668, 1997.

5. M. D. Morris, T. D. Jones, Hematopoietic death of unprotected man from photon irradiations-statistical modeling from animal-experiments. Int. J. Radiat. Biol. 55:445-461; 1989.

6. M. D. Morris, T. D. Jones, R. W. Young, A cell kinetics model of radiation-induced myelopoiesis-rate coefficient estimates for mouse, rat, sheep, swine, dog and burro irradiated by photons. Radiat. Res 135: 320-331; 1993.

7. M. D. Morris, T. D. Jones, A comparison of dose response models fro death from hematological depression in different species. Int J. Radiat. Bio. 53: 439-456; 1988.

8. NCRP, Guidance on Radiation Received in Space Activities. National Council on Radiation Protection, Report 98, 1989.

9. M.-H. Y. Kim, J. W. Wilson, F. A. Cucinotta, L. C. Simonsen, W. Atwell, F. F. Badavi, J. Miller, The local tissue environment during the September 29, 1989 Solar particle event. Adv. Space Res. (paper no. F2.3-0021, in press)

10. R. A. Nymmik, Space environment (natural and artificial) Probabilistic model for fluences and peak fluxes of Solar cosmic ray particles. International Standard ISO WD $15391,1997$.

11. T. F. Cleghorn, G. D. Badhwar, Comparison of the SPE model with proton and heavy ion data. Impact of Solar Energetic Particle Events for Design of Human Missions Workshop, September 9-11, 1997.

12. R. E. McGuire, T. T. von Rosenvinge, F. B. McDonald, The composition of Solar energetic particles. Astrophys. J. 301: 938-961; 1986.

13. A. J. Ross, B. Webbon, L. C. Simonsen, J. W. Wilson, Spacesuits. Shielding Strategies for Human Space Exploration. J. W. Wilson, J. Miller, A. Konradi, F. A. Cucinotta, eds. NASA CP 3360, pp. 283-296; 1997.

14. W. Atwell, M. D. Weyland, L. C. Simonsen, Solar particle dose rate buildup and distribution in critical body organs. Biological Effects and Physics of Solar and Galactic Cosmic Radiation. Part B., C. E. Swenberg, G. Horneck, and E. G. Stassinopoulos, eds. Plenum Press, pp. 831844; 1993.

15. J. W. Wilson, F. F. Badavi, F. A. Cucinotta, J. L. Shinn, G. D. Badhwar, R. Silberberg, C. H. Tsao, L. W. Townsend, R. K. Tripathi, HZETRN: Description of a Free-Space Ion and Nucleon Transport and Shielding Computer Program. NASA TP 3495, 1995.

16. T. Foelsche, R. B. Mendell, J. W. Wilson, R. R. Adams, Measured and calculated neutron spectra and dose equivalent rates at high altitudes: Relevance to SST operations and space research. NASA TN D-7715, 1974.

17. ICRP, 1990 Recommendations of the International Commission on Radiological Protection. ICRP Publ. 60, Pergamon Press Inc., 1991.

18. L. C. Simonsen, J. W. Wilson, Radiation exposure for human Mars exploration. NCRP 1998 Annual Meeting, to be published, 1999. 
Table 1. Fluence Levels of Solar Events of Cycle 19-22 Likely to Exceed Exposure Limits

\begin{tabular}{|l|l|l|c|c|}
\hline \multicolumn{3}{|c|}{ Date } & \multicolumn{2}{|c|}{ Fluence, protons/cm ${ }^{2}$, for energy of- } \\
\hline Month & Day & Year & $>10 \mathrm{MeV}$ & $>30 \mathrm{MeV}$ \\
\hline February & 23 & 1956 & $2 \times 10^{9}$ & $1 \times 10^{9}$ \\
July & $10-11$ & 1959 & $5 \times 10^{9}$ & $1 \times 10^{9}$ \\
July & $14-15$ & 1959 & $8 \times 10^{9}$ & $1 \times 10^{9}$ \\
July & $16-17$ & 1959 & $3 \times 10^{9}$ & $9 \times 10^{8}$ \\
aNovember & $12-13$ & 1960 & $8 \times 10^{9}$ & $2 \times 10^{9}$ \\
November & 15 & 1960 & $3 \times 10^{9}$ & $7 \times 10^{8}$ \\
July & 18 & 1961 & $1 \times 10^{9}$ & $3 \times 10^{8}$ \\
November & 18 & 1968 & $1 \times 10^{9}$ & $2 \times 10^{8}$ \\
April & $11-13$ & 1969 & $2 \times 10^{9}$ & $2 \times 10^{8}$ \\
January & $24-25$ & 1971 & $2 \times 10^{9}$ & $4 \times 10^{8}$ \\
bAugust & $4-9$ & 1972 & $2 \times 10^{10}$ & $8 \times 10^{9}$ \\
February & $13-14$ & 1978 & $2 \times 10^{9}$ & $1 \times 10^{8}$ \\
April & 30 & 1978 & $2 \times 10^{9}$ & $3 \times 10^{8}$ \\
September & $23-24$ & 1978 & $3 \times 10^{9}$ & $4 \times 10^{8}$ \\
May & 16 & 1981 & $1 \times 10^{9}$ & $1 \times 10^{8}$ \\
October & $9-12$ & 1981 & $2 \times 10^{9}$ & $4 \times 10^{8}$ \\
February & $1-2$ & 1982 & $1 \times 10^{9}$ & $2 \times 10^{8}$ \\
April & $25-26$ & 1984 & $1 \times 10^{9}$ & $4 \times 10^{8}$ \\
August & $12-\ldots$ & 1989 & $8 \times 10^{9}$ & $2 \times 10^{8}$ \\
September & $29-\ldots$ & 1989 & $4 \times 10^{9}$ & $1 \times 10^{9}$ \\
October & $19-\ldots$ & 1989 & $2 \times 10^{10}$ & $4 \times 10^{9}$ \\
November & $26-\ldots$ & 1989 & $2 \times 10^{9}$ & $1 \times 10^{8}$ \\
\hline
\end{tabular}

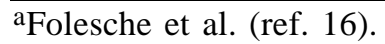

bWilson et al. (ref. 4).

Table 2. Recommended Organ Dose Equivalent Limits [From NCRP 98 (ref. 8)]

\begin{tabular}{|c|c|c|c|}
\hline \multirow{2}{*}{$\begin{array}{c}\text { Exposure } \\
\text { interval }\end{array}$} & \multicolumn{3}{|c|}{ Dose equivalent, Sv, for- } \\
\cline { 2 - 4 } & Blood forming organ & Skin & Ocular lens \\
\hline Career & ${ }^{\mathrm{a}} 1-4$ & 6 & 4 \\
Annual & 0.5 & 3 & 2 \\
30 days & 0.25 & 1.5 & 1 \\
\hline
\end{tabular}

${ }^{a}$ Varies with age and gender at initial exposure. 
Table 3. Material layups (from exterior to interior) for the helmet extravehicular visor assembly (EVVA) of the Shuttle spacesuit assembly

\begin{tabular}{llc}
\hline Layer & Material & $\begin{array}{c}\text { Areal density } \\
\left(\mathrm{g} / \mathrm{cm}^{2}\right)\end{array}$ \\
\hline Outer layer & Orthofabric cover - Teflon/Nomex/Kevlar & 0.049 \\
Insulation & Reinforced aluminized Mylar -5 plies & 0.004 \\
Spacer & Non-woven Dacron -5 plies & 0.011 \\
Inner liner & Teflon & 0.028 \\
EVVA shell & Polycarbonate & 0.381 \\
Sun visor & Poplysufone & 0.190 \\
Eye shades & Polysufone & 0.190 \\
Protective visor & Polycarbonate & 0.182 \\
Helmet bubble & Polycarbonate & 0.182 \\
\hline
\end{tabular}

Table 4. Material layups (from exterior to interior) for the lower torso assembly (LTA), arms, and legs of the Shuttle suit assembly covering the brief area, arms, and legs of the astronaut.

\begin{tabular}{llc}
\hline Layer & Material & $\begin{array}{c}\text { Areal density } \\
\left(\mathrm{g} / \mathrm{cm}^{2}\right)\end{array}$ \\
\hline Outer layer & Orthofabric cover - Teflon/Nomex/Kevlar & 0.049 \\
Insulation & Reinforced aluminized Mylar -5 plies & 0.014 \\
Inner liner & Neoprene coated ripstop & 0.028 \\
Pressure restraint & Dacron & 0.021 \\
Pressure bladder & Urethane coated nylon ripstop & 0.014 \\
LCVG & Spandex/water/ethylvinylacetate & 0.154 \\
\hline
\end{tabular}

Table 5. Exposure Levels for Single, High-Dose Rate Exposure at Which Health Effects Appear in Healthy Adults

[From ref. 8]

\begin{tabular}{|c|c|}
\hline Health effect & $\begin{array}{l}\text { Dose, } \mathrm{X} \text { or gamma } \\
\text { radiation, } \mathrm{Gy}\end{array}$ \\
\hline 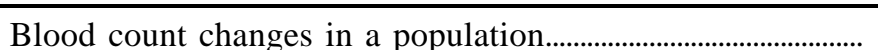 & $0.15-0.25$ \\
\hline 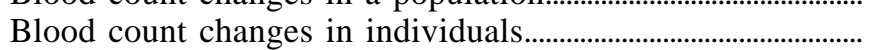 & 0.5 \\
\hline 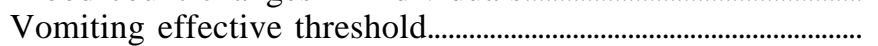 & 1.0 \\
\hline 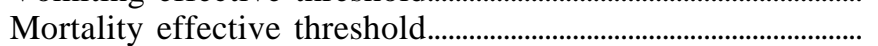 & 1.5 \\
\hline 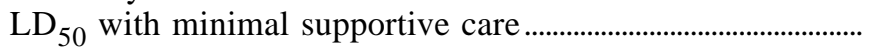 & $3.2-3.6$ \\
\hline 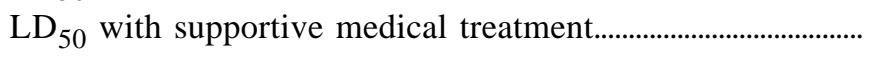 & $4.8-5.4$ \\
\hline 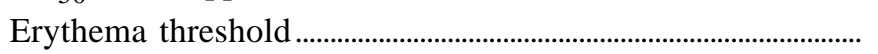 & 6.0 \\
\hline Moist desquamation & 30.0 \\
\hline
\end{tabular}


Table 6. Dose equivalent from the worst case SPE in free space (in $c S v$ )

\begin{tabular}{|c|c|c|c|c|c|c|c|c|c|c|c|c|}
\hline & \multicolumn{4}{|c|}{ Skin } & \multicolumn{4}{|c|}{ Ocular lens } & \multicolumn{4}{|c|}{$\mathrm{BFO}$} \\
\hline Charge & $\begin{array}{l}\text { Space- } \\
\text { suit }\end{array}$ & $\begin{array}{c}\text { Pressure } \\
\text { vessel }\end{array}$ & $\begin{array}{l}\text { Equipment } \\
\text { room }\end{array}$ & Shelter & $\begin{array}{l}\text { Space- } \\
\text { suit }\end{array}$ & $\begin{array}{c}\text { Pressure } \\
\text { vessel }\end{array}$ & $\begin{array}{l}\text { Equipment } \\
\text { room }\end{array}$ & Shelter & $\begin{array}{l}\text { Space- } \\
\text { suit }\end{array}$ & $\begin{array}{c}\text { Pressure } \\
\text { vessel }\end{array}$ & $\begin{array}{l}\text { Equipment } \\
\text { room }\end{array}$ & Shelter \\
\hline $\mathrm{Z}=1$ & 17,380 & 5,540 & 577 & 226 & 6,680 & 3,180 & 501 & 213 & 378 & 314 & 168 & 106 \\
\hline$Z=2$ & 11,490 & 820 & 66 & 35 & 1,330 & 330 & 49 & 29 & 40 & 35 & 24 & 19 \\
\hline $3 \leq Z \leq 10$ & 530 & 50 & 2 & $<1$ & 90 & 20 & 2 & $<1$ & 1 & 1 & $<1$ & $<1$ \\
\hline $11 \leq \mathrm{Z} \leq 20$ & 90 & 20 & 1 & $<1$ & 20 & 10 & 1 & $<1$ & 1 & 1 & $<1$ & $<1$ \\
\hline $21 \leq Z \leq 28$ & 20 & 10 & 2 & $<1$ & 10 & 10 & 1 & $<1$ & 1 & 1 & $<1$ & $<1$ \\
\hline Total & 29,510 & 6,440 & 648 & 262 & 8,130 & 3,550 & 554 & 243 & 421 & 352 & 193 & 126 \\
\hline $\begin{array}{c}\text { NCRP } \\
\text { 30-day limit }\end{array}$ & \multicolumn{4}{|c|}{150} & \multicolumn{4}{|c|}{100} & \multicolumn{4}{|c|}{25} \\
\hline
\end{tabular}

Table 7. Dose equivalent from the worst case SPE on Lunar surface (in $c S v$ )

\begin{tabular}{|c|c|c|c|c|c|c|c|c|c|c|c|c|}
\hline \multirow[b]{2}{*}{ Charge } & \multicolumn{4}{|c|}{ Skin } & \multicolumn{4}{|c|}{ Ocular lens } & \multicolumn{4}{|c|}{$\mathrm{BFO}$} \\
\hline & $\begin{array}{l}\text { Space- } \\
\text { suit }\end{array}$ & $\begin{array}{c}\text { Pressure } \\
\text { vessel }\end{array}$ & $\begin{array}{l}\text { Equipment } \\
\text { room }\end{array}$ & Shelter & $\begin{array}{l}\text { Space- } \\
\text { suit }\end{array}$ & $\begin{array}{c}\text { Pressure } \\
\text { vessel }\end{array}$ & $\begin{array}{l}\text { Equipment } \\
\text { room }\end{array}$ & Shelter & $\begin{array}{l}\text { Space- } \\
\text { suit }\end{array}$ & $\begin{array}{c}\text { Pressure } \\
\text { vessel }\end{array}$ & $\begin{array}{l}\text { Equipment } \\
\text { room }\end{array}$ & Shelter \\
\hline $\mathrm{Z}=1$ & 8,690 & 2,770 & 289 & 113 & 3,340 & 1,590 & 251 & 107 & 189 & 157 & 84 & 53 \\
\hline $\mathrm{Z}=2$ & 5,745 & 410 & 33 & 18 & 665 & 165 & 25 & 15 & 20 & 18 & 12 & 10 \\
\hline $3 \leq \mathrm{Z} \leq 10$ & 265 & 25 & 1 & $<1$ & 45 & 10 & 1 & $<1$ & $<1$ & $<1$ & $<1$ & $<1$ \\
\hline $11 \leq Z \leq 20$ & 45 & 10 & $<1$ & $<1$ & 10 & 5 & $<1$ & $<1$ & $<1$ & $<1$ & $<1$ & $<1$ \\
\hline $21 \leq Z \leq 28$ & 10 & 5 & 1 & $<1$ & 5 & 5 & $<1$ & $<1$ & $<1$ & $<1$ & $<1$ & $<1$ \\
\hline Total & 14,755 & 3,220 & 324 & 131 & 4,065 & 1,775 & 277 & 122 & 211 & 176 & 97 & 63 \\
\hline $\begin{array}{c}\text { NCRP } \\
\text { 30-day limit }\end{array}$ & & & 150 & & & & 00 & & & & 5 & \\
\hline
\end{tabular}

Table 8. Dose equivalent from the worst case SPE on Martian surface (in $c S v$ )

\begin{tabular}{|c|c|c|c|}
\hline & Skin & Ocular lens & BFO \\
\hline Spacesuit & 45 & 44 & 32 \\
\hline Helmet/Pressure vessel & 44 & 42 & 28 \\
\hline Equipment room & 38 & 37 & 25 \\
\hline Shelter & 33 & 32 & \\
\hline
\end{tabular}




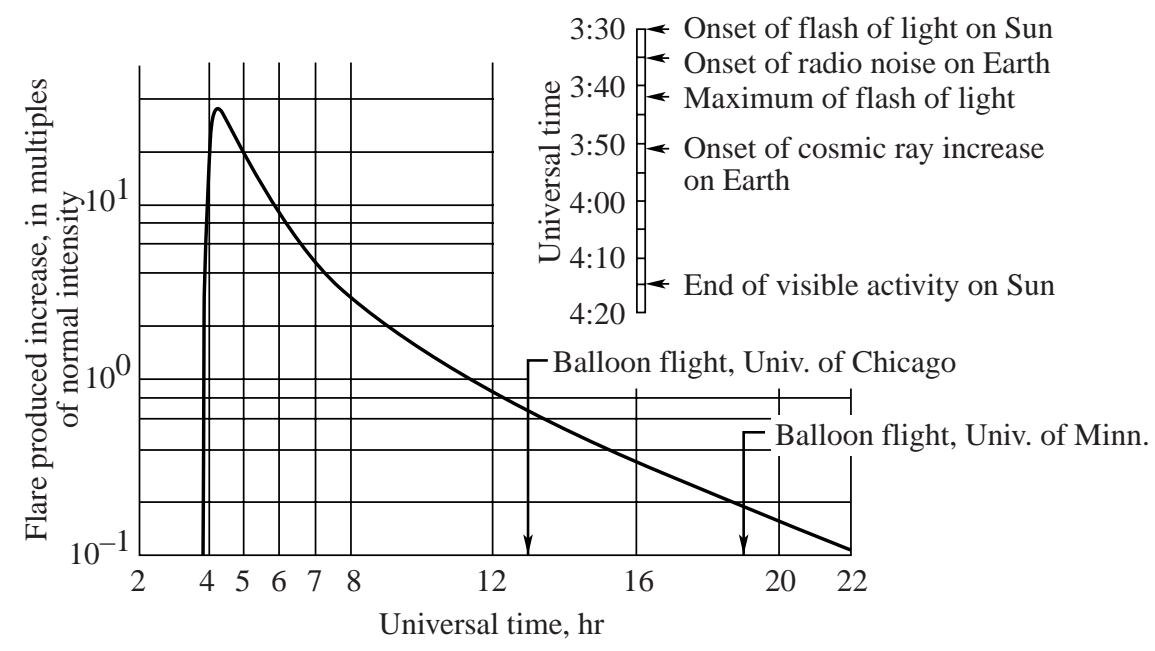

Figure 1. Ground level neutron monitor event seen at Durham, NH on Feb. 23, 1956. (Schaefer 1959).

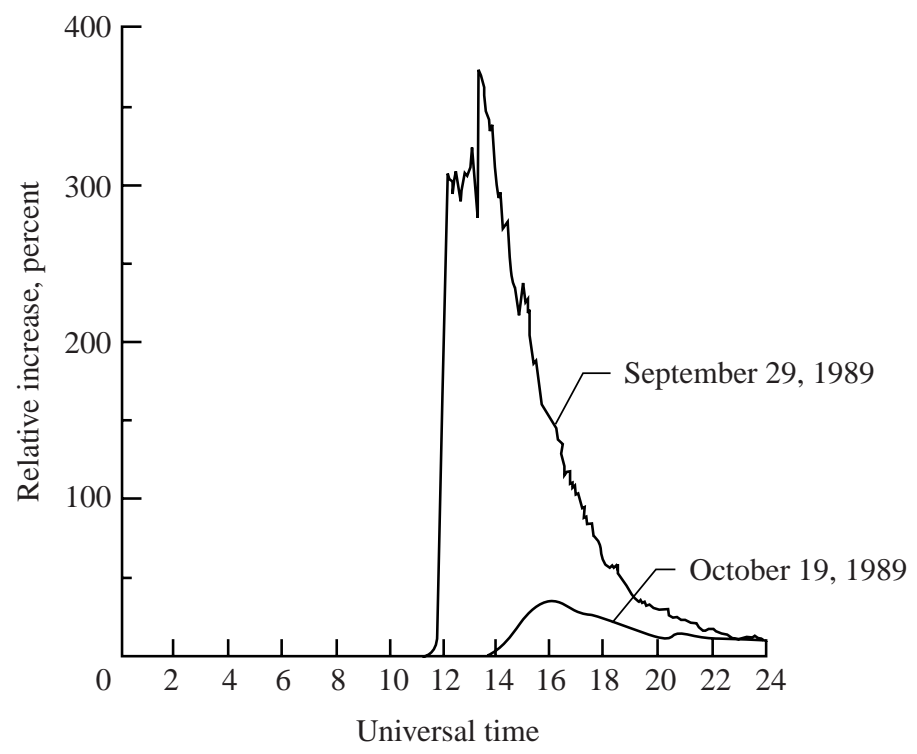

Figure 2. Deep River neutron monitor count rates during the solar particle events of October 19 and September 29 of 1989. 


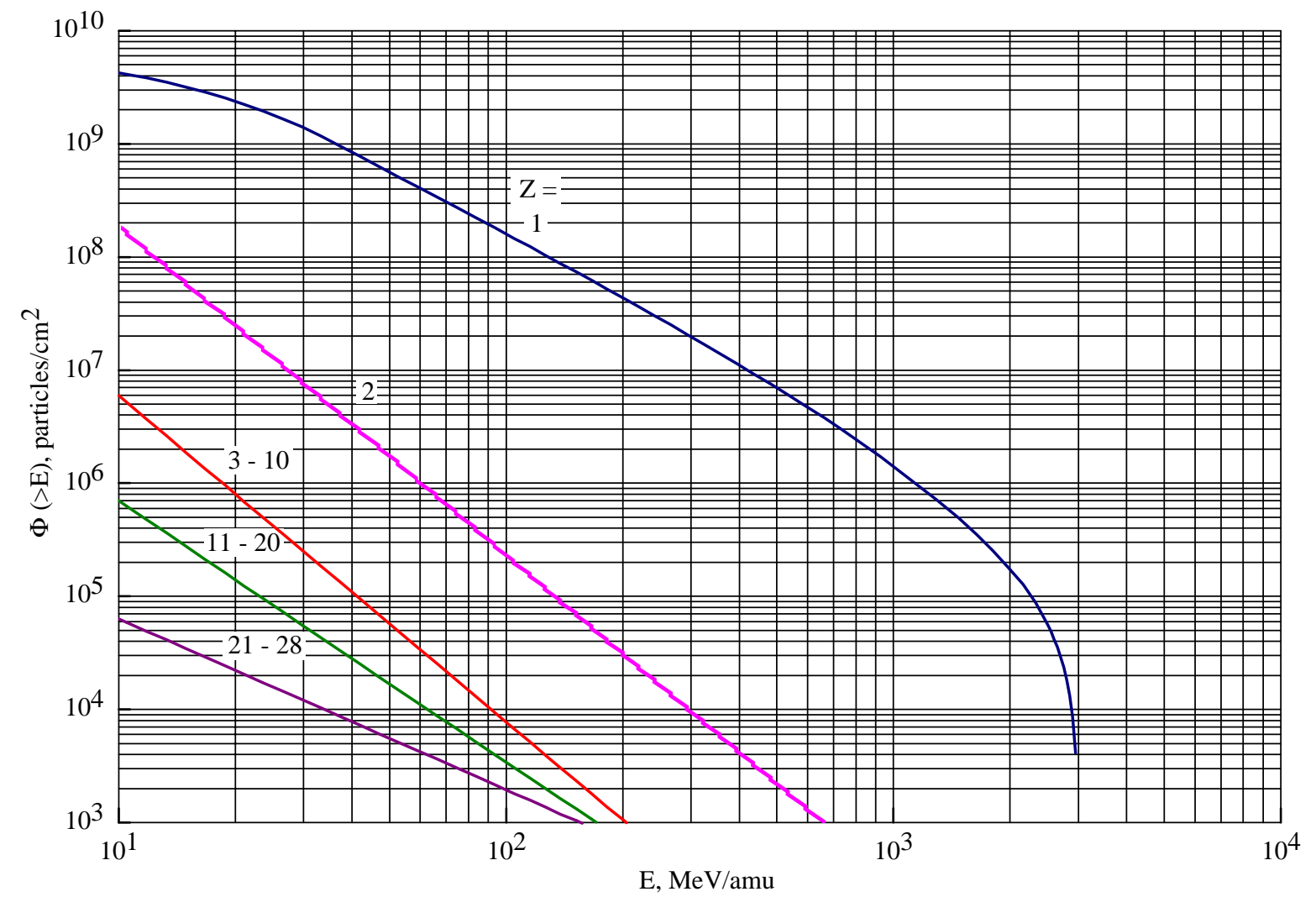

Figure 3. Event-integrated fluence spectra of the September 29, 1989 SPE. 


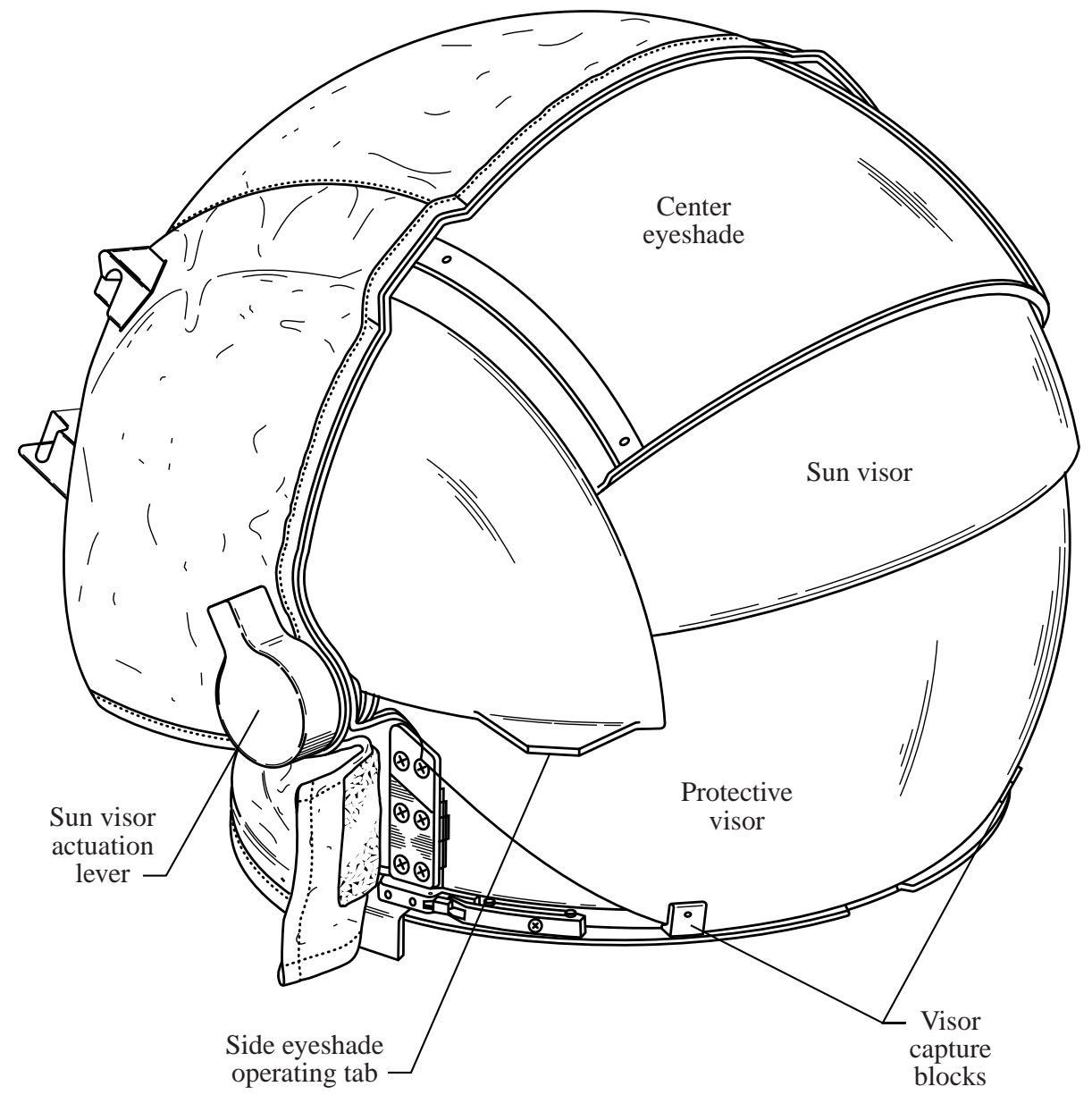

Figure 4. Illustration of helmet extravehicular visor assembly (EVVA) showing placement of visors and eyeshades. 


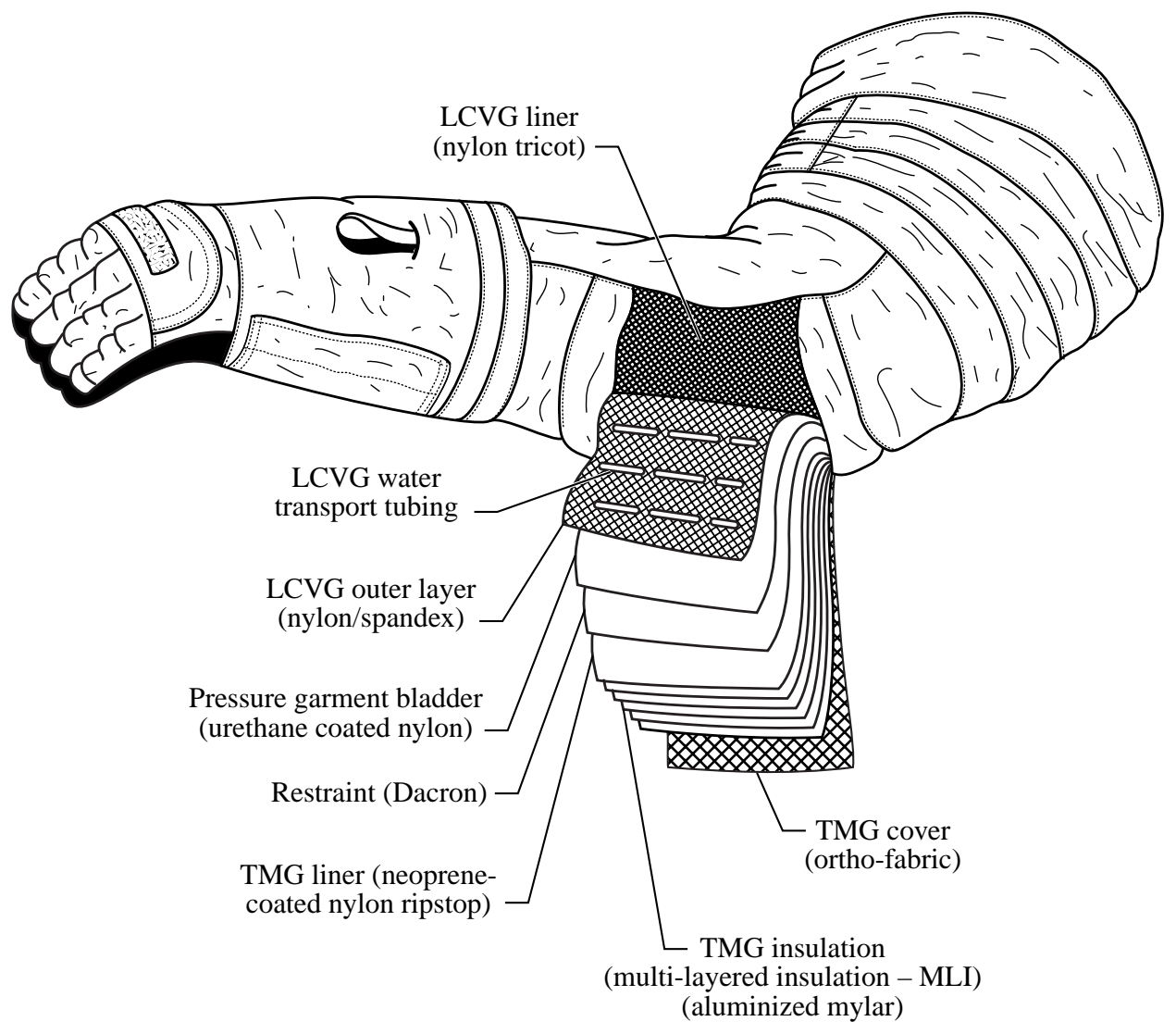

Figure 5. Cross section of material layup used for fabric for the arms and legs of the spacesuit. 


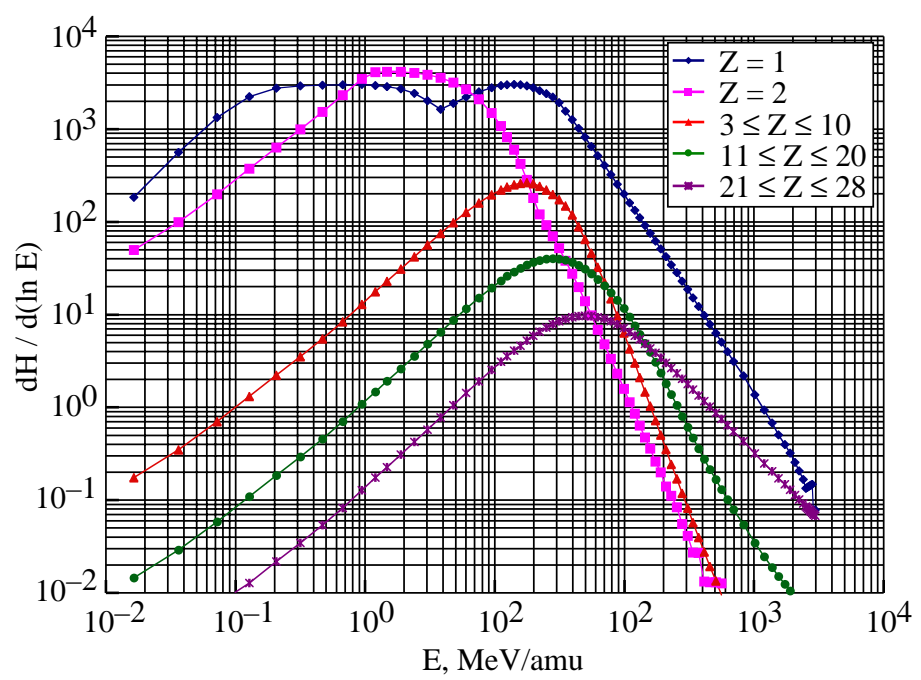

(a) Skin dose equivalent in spacesuit.

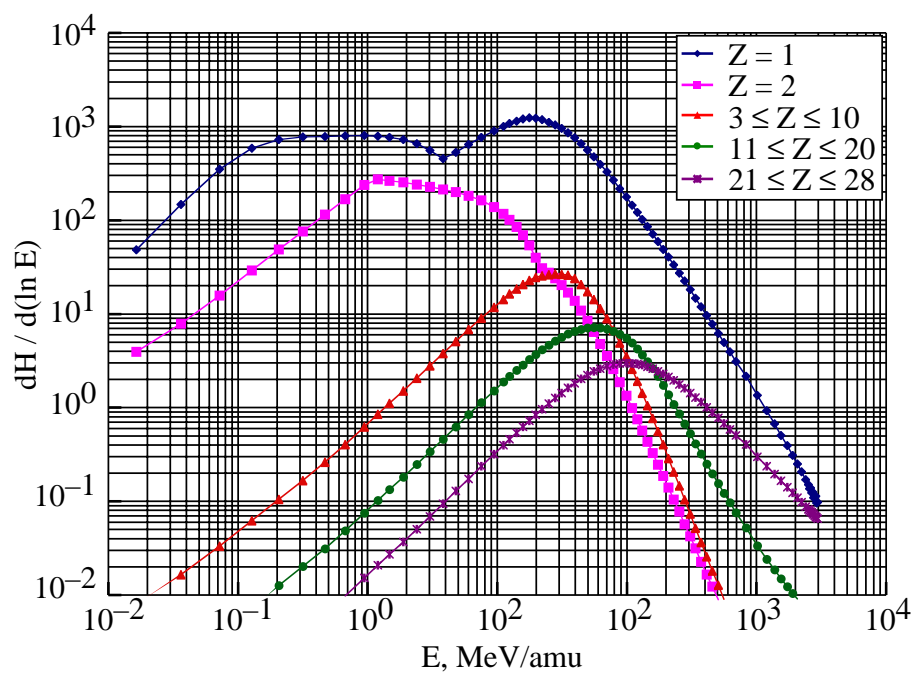

(c) Skin dose equivalent in pressure vessel.

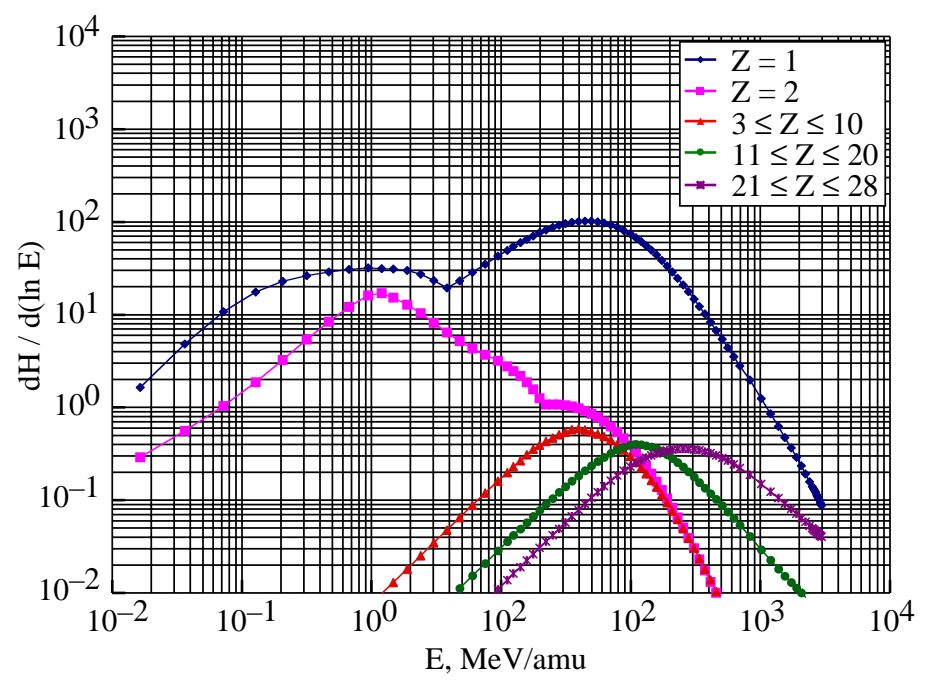

(b) BFO dose equivalent in spacesuit.

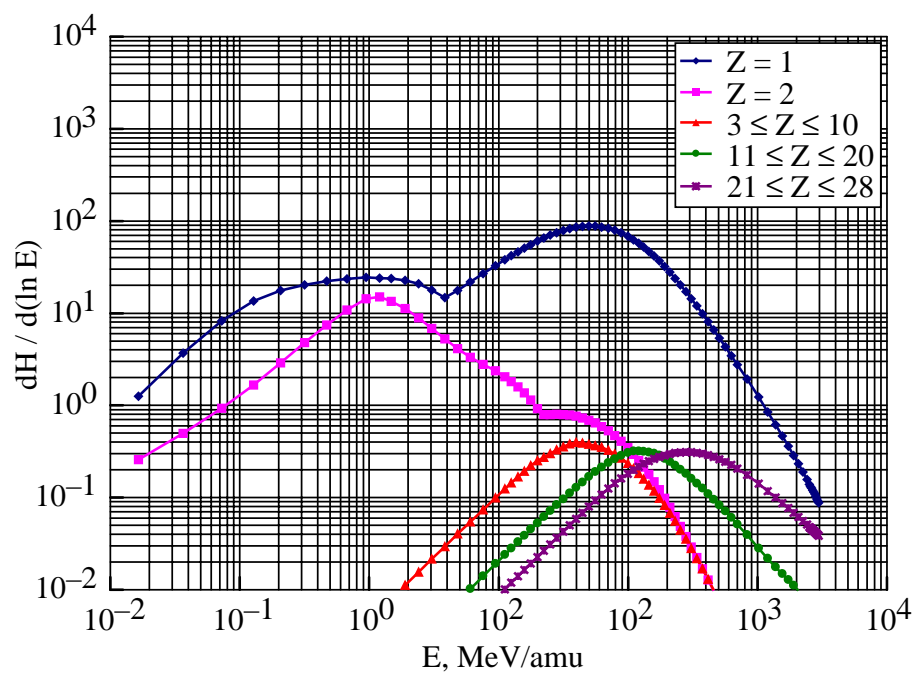

(d) BFO dose equivalent in pressure vessel.

Figure 6. Dose equivalent form the worst case SPE exposure at free space. 


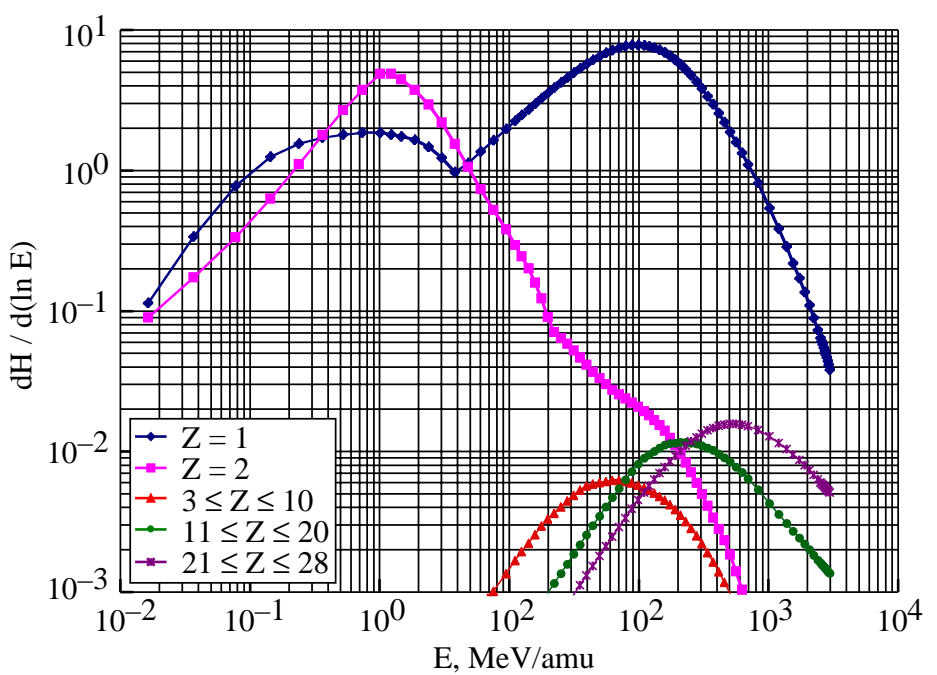

(a) Skin dose equivalent in spacesuit.

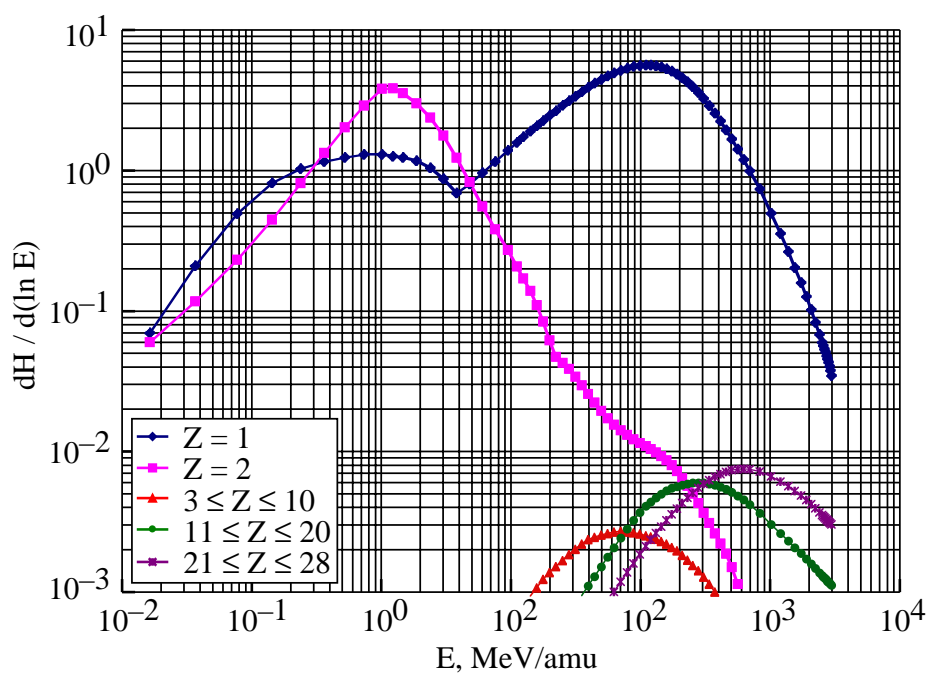

(b) BFO dose equivalent in spacesuit.

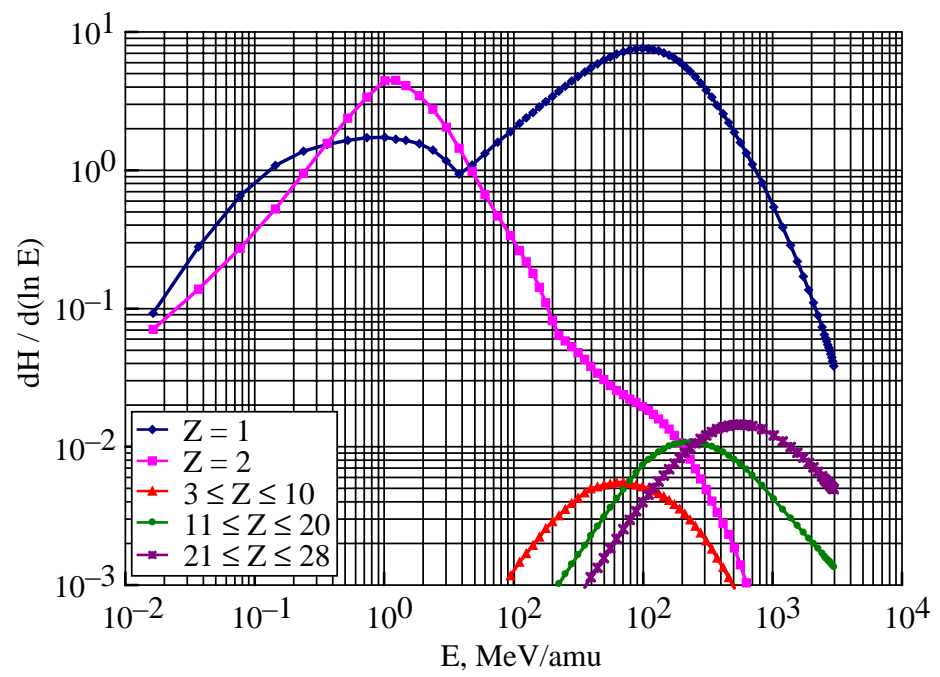

(c) Ocular lens dose equivalent in helmet.

Figure 7. Dose equivalent from the worst case SPE exposure on Martian surface. 


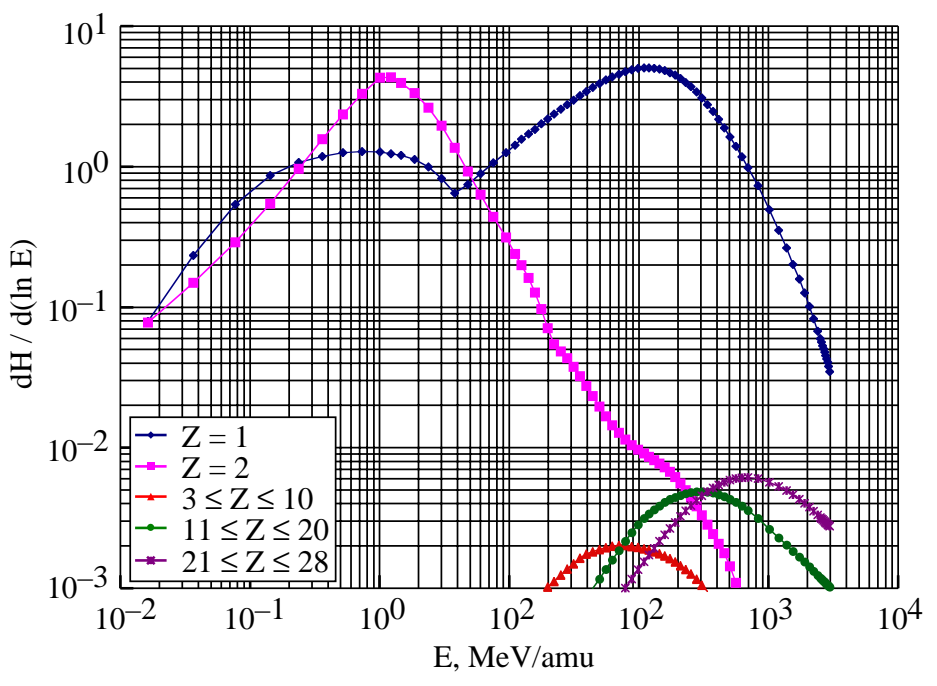

(a) Skin dose equivalent in shelter.

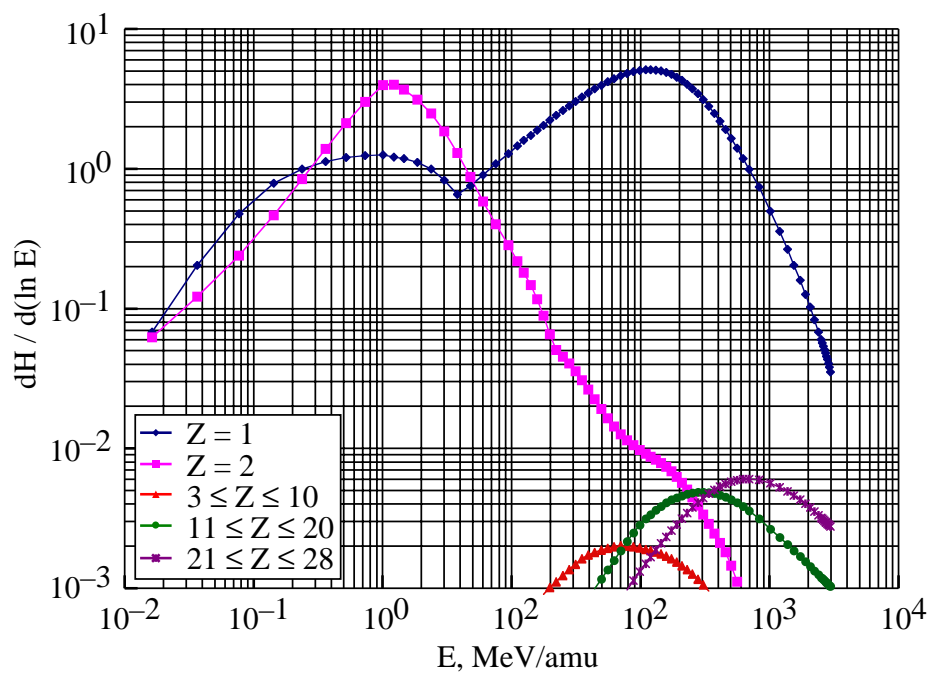

(b) Ocular lens dose equivalent in shelter.

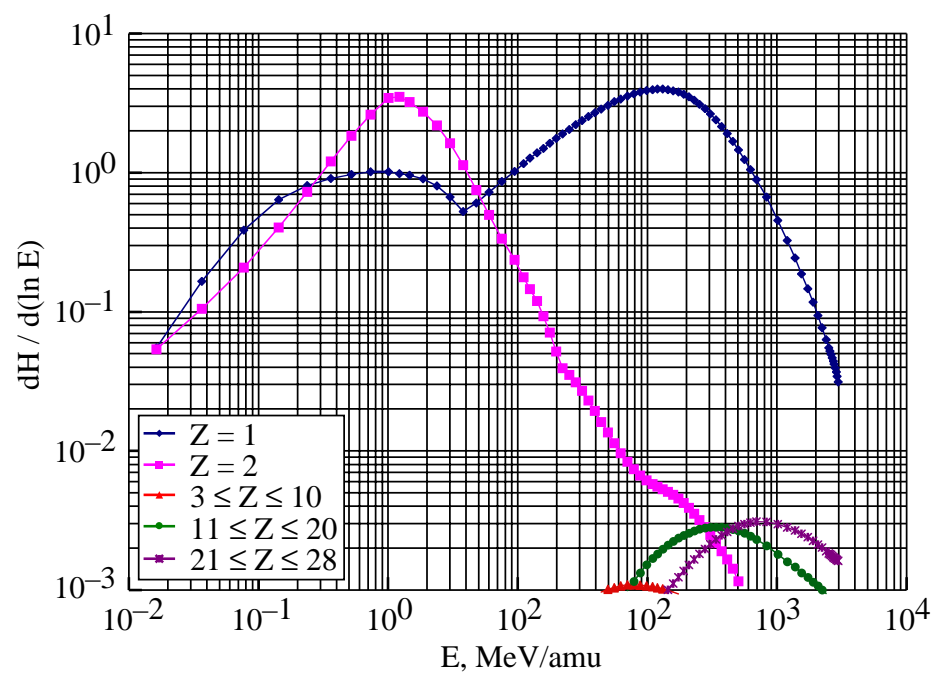

(c) BFO dose equivalent in shelter.

Figure 8. Dose equivalent inside shelter from the worst case SPE exposure on Martian surface. 